\title{
Modeling the risks of marine submersion on the Saidia coastal- Cap de l'Eau (Northeast Morocco)
}

\author{
Samhane Ramdani ${ }^{1}$, Mostafa Oujidi ${ }^{1}$, Najat Amarjouf ${ }^{2}$, Hafssa Afif ${ }^{1}$, and Abdellah Azougay ${ }^{1}$ \\ ${ }^{1}$ Applied Geosciences Laboratory (LGA), Department of Geology, Faculty of Sciences Oujda - FSO, Mohammed Premier University. \\ ${ }^{2}$ Research and Development in Engineering Sciences Laboratory "LRDSI", Department of Earth and Environmental Sciences, Faculty \\ of Science and Technology Al Hoceima - FSTH, Abdelmalek Essaadi University, Tetouan.
}

\begin{abstract}
The coastline is an area of ecological and environmental balance between the continent and the sea. The coastline from Saidia to Cap de l'Eau, located on the Mediterranean coast of Morocco, is the subject of this study. The goal of this work is to produce maps of the risk of marine submersion. The methodology followed consists of entering storm meteorological data and land use data into the Iber 2D software. In addition, we mapped the hazard as well as the vulnerability of this submersion. The results of this 2D modeling of the hazard have shown that the coastline of Saidia - Cap de l'Eau presents a high risk of marine submersion, and this by the water levels rises to more than 4 meters and overflow on a width of more than 20 meters towards the mainland. In addition, the coastal strip constitutes a zone of high vulnerability compared to the continent.
\end{abstract}

\section{Introduction}

The Mediterranean coastline is exposed to several natural hazards that promote its vulnerability and degradation following the concentration of projects and socio-economic activities that involve human issues, property, and infrastructure, facing a significant influence to a risk of marine submersion, coastal erosion, and even a tsunami-genic risk. The coastline of Saidia Cap de l'Eau extends over $20 \mathrm{~km}$, which presents a pole of attraction and essential investment of national interest. [1]

Presumably, this coastline is threatened by a major risk of marine submersion that could invade a vast area involving human lives, property, and infrastructure. The existence of this risk of marine submersion, which consequently contributes to a specific rise in water level along the said coastline, is well illustrated in the 2D modeling of the hazard carried out on Iber software.

\section{The study area}

The study area extends from Saïdia to Cap de l'Eau, is located in the North-East of Morocco. It has a $20 \mathrm{~km}$ long coastline, limited by the Mediterranean Sea in the North, the Ouled Mansour Mountains and Triffa Plain in the South, the Kiss stream on the Moroccan-Algerian border in the East the Kebdana in the West (Fig. 1).

The Saidia-Cap de l'Eau coastline enjoys a rather contrasting Mediterranean climate, marked by an increasingly accentuated aridity, an average annual rainfall of $320 \mathrm{~mm} /$ year, and an average annual temperature of $17^{\circ} \mathrm{C}$.

The coastline of Saidia - Cap de l'Eau is generally constituted by the current to recent quaternary deposits and middle and ancient continental quaternary, plioquaternary volcano-sedimentary, and the presence of a neogenous volcanism. [2]

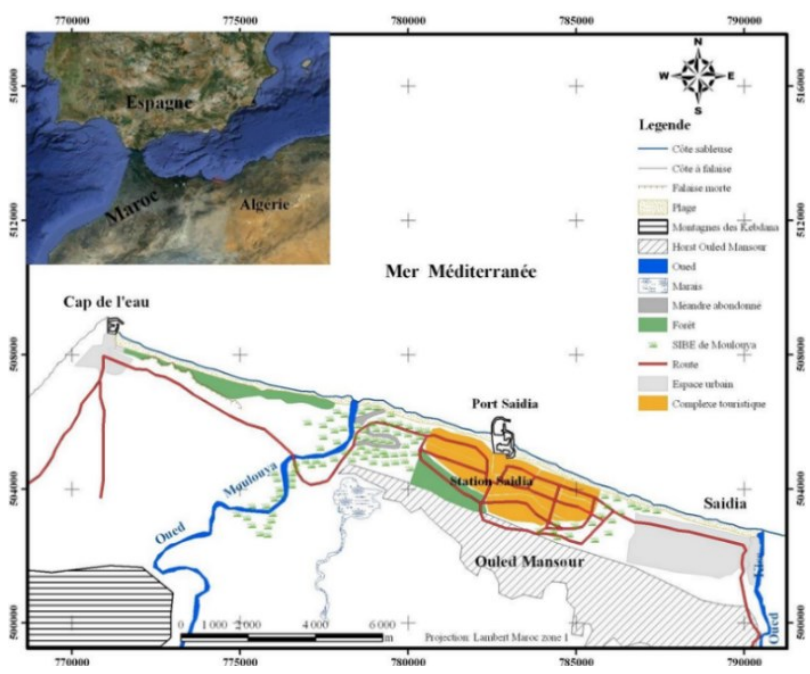

Fig. 1. The map of the situation of the study area [2]

This coastline is dominated by swells which are of North-West and North-East direction. Their interference generates a dominant littoral drift with a WNW-ESE direction. This is evidenced on the left bank of the mouth of the Moulouya by the coastal arrow very developed parallel to the shoreline characterizing the coastline dominated by the swell.

\footnotetext{
* Corresponding author: smahane.ramdani@ump.ac.ma
} 


\section{Materials \& Methods}

The present study concretizes the existence of the risk of marine submersion at the level of the littoral of Saidia Cap de l'Eau, by making the conjunction of the hazard, the vulnerability, and the stakes, and this by pursuing an appropriate scientific protocol which is based on a treatment of the system of geographical information on ArcGis, and modeling in 2D on Iber software for the elaboration of the maps and the relevant results. [3]

Table 1. Primary data for the realization of the modeling

\begin{tabular}{|c|c|c|c|}
\hline DEM & $\begin{array}{c}\text { Resolution/ } \\
\text { coordinates }\end{array}$ & Softwares & Data used \\
\hline Satellite & $35.5 \mathrm{~m}$ & $\begin{array}{c}\text { Global } \\
\text { Mapper }\end{array}$ & $\begin{array}{c}\text { Digital model } \\
\text { and terrain } \\
\text { topography }\end{array}$ \\
\hline $\begin{array}{c}\text { Storm } \\
\text { Data }\end{array}$ & -2.24 & Mapuzzle & $\begin{array}{c}\text { Land use and } \\
\text { vulnerability }\end{array}$ \\
\hline
\end{tabular}

The table above summarizes the primary data needed to model the risk of marine flooding on Iber 2D software and its characteristics.

The work methodology follows an explicit scientific protocol that addresses the path of the elaboration of the maps as a result. It is subdivided into two (02) parts; the first one on ArcGis contributes to preparing the data and their processing, and the other one on Iber realizes the 2D simulation of the marine submersion hazard. In ArcGis, the primary data processing is carried out, which is the object of the first step, and then the second part is started, whose main goal is to carry out the $2 \mathrm{D}$ simulation in Iber. [4] [5] and [6].

The indicated approach must be carefully carried out to achieve the main objective of this study, which is based on the simulation and the elaboration of different maps that define the marine submersion hazard, the risk intensity, and the stakes.

\section{Results and Discussions}

The results obtained are the crucial object of this study, divided into two essential parts: one carried out on ArcGIS and the other on Iber following an appropriate methodology. This study led to the elaboration of several maps, which highlighted the different entities that compose the area and its vulnerability.

Using ArcGIS software, we determined the land use map that summarizes the most important entities on the site: river, dense vegetation, forest, brushland, infrastructure, sand, and residential, as illustrated in figure 2 .

This will subsequently help realize the vulnerability map, which is defined by three classes of vulnerability ( 0 - $0.5-1$ ) classified by order of importance, as illustrated in figure 3 .

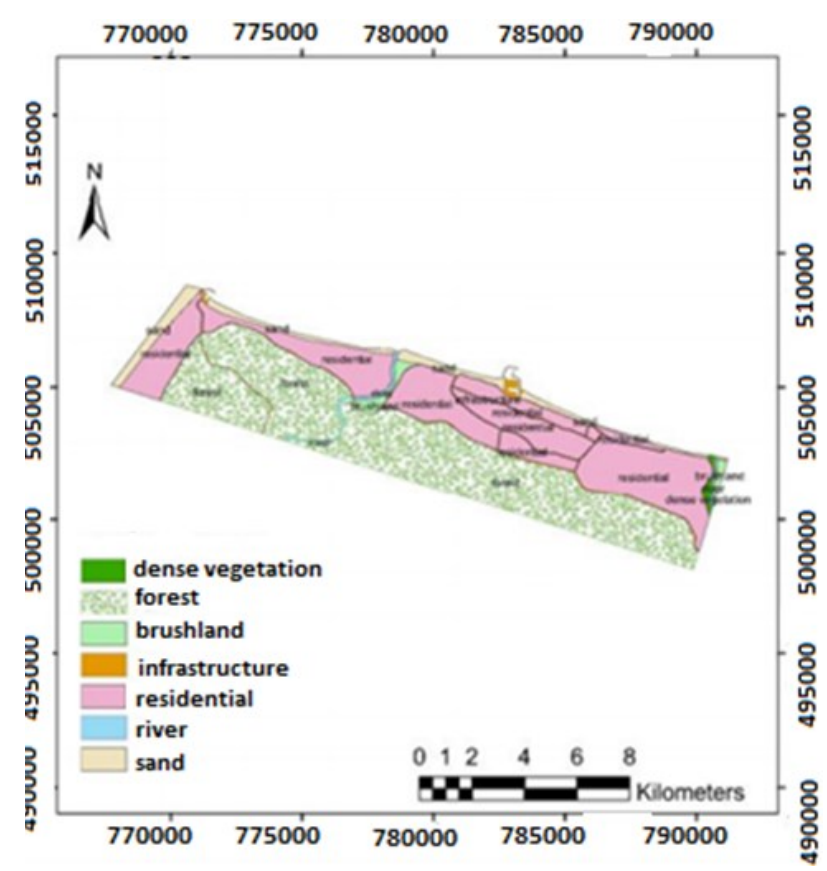

Fig. 2. The map of the land-use study area 770000775000780000785000790000795000

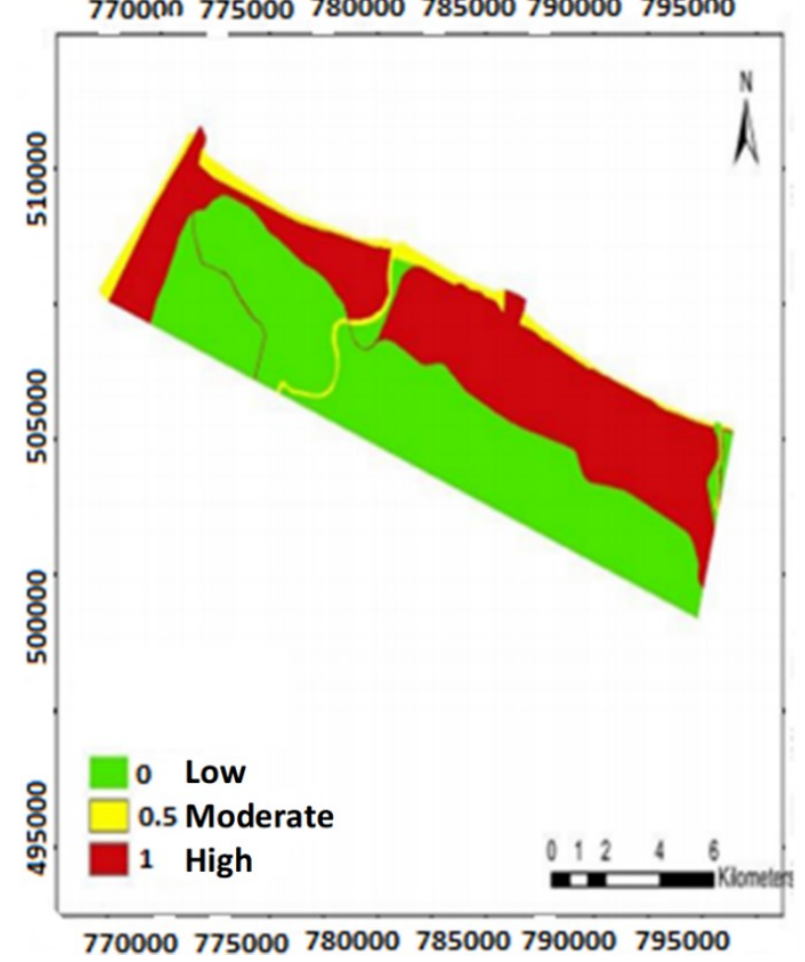

Fig. 3. Map of the vulnerability study area

In order to refine the results obtained, the study area is divided into two sectors: (figure 4)

\section{Sector 1:}

- From Saidia to the mouth of the Moulouya:

The 2D modeling carried out on Iber has allowed obtaining a result composed of three parameters: (1) water velocity, (2) water depth, and (3) water elevation, which predefine the intensity of the risk of marine submersion as well as the vulnerability of the concerned coastline. In addition, other factors condition the risk of marine submersion, namely: the topography of the land, the intensity of the topography of the land, the intensity 
of the meteorological storm that will favor the elevation of marine waters.

\section{Sector 2:}

- From the mouth of the Moulouya to Cap de l'Eau:

The results obtained show that we have a high vulnerability near the coastline from the mouth of the Moulouya arriving at Cap de l'Eau Moreover, or the depth of water varies between $2 \mathrm{~m}$ to $0 \mathrm{~m}$ from the sea approaching the coastline and is well-illustrated in the area so close to the mouth of the Moulouya.

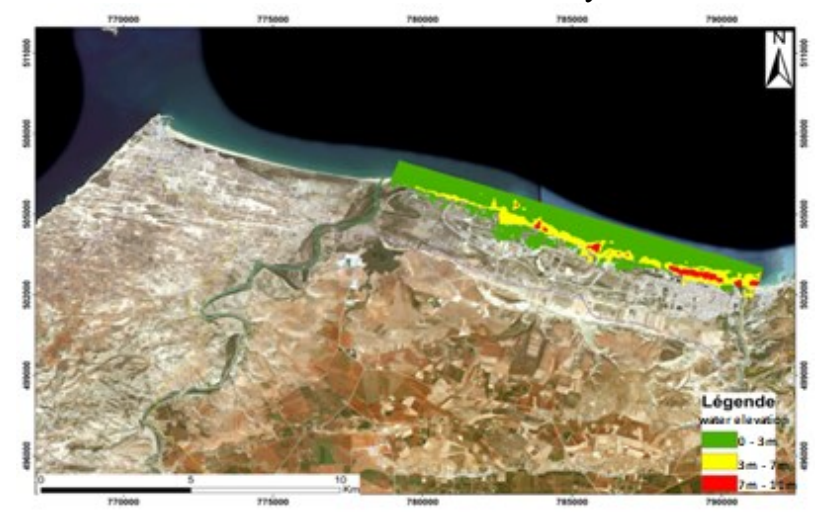

Fig. 4. The map of water elevation

Figure 4 illustrates the simulation result on Iber 2D, which shows a rise in water along the coastline following a storm that will promote the amplification of wave heights.

\section{Conclusion}

The risk of marine submersion would impact the coastline of Saidia-Cap de l'Eau and would have caused some damage that would generally affect the low points of the coastline. Hence the rise in sea level, in connection with global climate change. Thus, the rise in sea level will undoubtedly increase the recurrence of this risk. This work of mapping by two-dimensional hydraulic modeling has shown us good results regarding the risk of marine submersion on the eastern coast of the Mediterranean. Moreover, that consequently can generate an overflow of marine waters of a speed that can reach $3 \mathrm{~m} / \mathrm{s}$ during an assignment of the coastline by the hazard of marine flooding.

\section{Acknowledgment}

The authors would also like to extend their sincerest gratitude to the anonymous reviewers for their thoughtful comments and suggestions for improving this manuscript.

\section{References}

1. MOUZOURI M., IRZI Z., Évolution et morphodynamique de la plaine côtière de Saïdia (littoral méditerranéen du Nord-Est du Maroc durant la période 1958-2006). Bulletin de l'Institut Scientifique, Rabat, section Sciences de la Terre, 2011, N³3, p. 65-76.

2. LASGAA H; BOUMEAZA T; SBAI A; Le littoral méditerranéen $\mathrm{du}$ nord-est du Maroc entre dégradation du patrimoine naturel et nécessité de la Gestion Intégrée des Zones Côtières. Actes de la table ronde « La Gestion Intégrée des Zones Côtières », 2010. P. 40-54

3. A. M. Da COSTA LOMBA, OUJIDI M, AMARJOUF N, Apport de la modélisation 2D dans la cartographie préliminaire de l'aléa de submersion marine, cas de la côte de Luanda, Angola (Afrique Ouest), (3ème édition du colloque international des utilisateurs du SIG, P27. 2016.

4. AMARJOUF, N., "Interactions entre cruesruissellements et aménagements de territoire et leurs impacts sur les versants Nord de la péninsule de Guelâaya: Cas de la baie de Melilla Béni Ansar et la baie de Betoya." (Maroc Nord Oriental).Thèse de Doctorat, Faculté des sciences, Université Mohamed Premier, Oujda. 302. 2018.

5. IBER, (a). Hydraulic Reference Manual for IBER V1.0. 2010

6. IBER, (b). Tutorial; Tossa. 2010. 